\title{
ANALISIS KINERJA KEUANGAN PADA PT BAYAN RESOURCE Tbk Per 2015-2017
}

\author{
Muhammad Maulana \\ University of 17 Agustus 1945 Samarinda \\ Jl. Ir. H. Juanda No. 80, 75124, Indonesia \\ mm.juve@gmail.com
}

\begin{abstract}
Company performance is an illustration of the financial condition of a company by conducting a financial analysis, so that it can be known about the good and bad financial condition of a company that reflects work performance in a certain period. To find out how good a company's financial performance is, it is necessary to conduct an assessment and performance measurement. One assessment and measurement of performance can be reflected through an analysis of financial ratios.

This research was conducted to find out how well the financial performance performed by PT Bayan resources a coal mining company in the 2015-2017 period by analyzing the ratio of: (1) profitability ratios (2) solvency ratios, (3) liquidity ratios, (4) activity ratio. The hypothesis of this research is based on the phenomenon, which is based on the market value of coal which has decreased over the period of 2015-2017.

Based on the results of the study, the hypothesis for calculating profitability ratios, activity ratios and solvency ratios is proven to be acceptable, while the hypothesis for liquidity ratios is not proven, namely rejected, meaning that fluctuations in coal price increases can result in the use of corporate liquidity to pay company bills so that the level of liquidity of the company can be reduced
\end{abstract}

Keywords: Profitability Ratio, Solvency Ratio, Liquidity, Activity Ratio

PENDAHULUAN

Perusahaan sebagai salah satu bentuk organisasi pada umumnya memiliki tujuan tertentu yang ingin dicapai dalam usaha untuk memenuhi kepentingan para anggotanya. Keberhasilan dalam mencapai tujuan perusahaan merupakan prestasi manajemen. Penilaian prestasi atau kinerja suatu perusahaan diukur karena dapat dipakai sebagai dasar pengambilan keputusan baik pihak internal maupun eksternal.
Manajemen keuangan sangat berpengaruh terhadap kelangsungan kegiatan dan ekstensi suatu perusahaan serta berpengaruh pula pada setiap individu yang ada dalam perusahaan tersebut. Tambang adalah tempat terjadinya kegiatan penambangan. Pertambangan adalah rangkaian kegiatan dalam rangka upaya pencarian, penambangan (penggalian), pengolahan, pemanfaatan dan penjualan bahan galian (mineral, batu bara, panas bumi, migas). Perusahaan pertambangan batu 
bara adalah kegiatan dan bisnis yang berkaitan dengan industri pertambangan mulai dari prospeksi, eksplorasi, evaluasi, penambangan, pengolahan, pemanfaatan, pengangkutan, sampai pemasaran.

PT Bayan Resources Tbk (Perseroan) atau Bayan Group merupakan produsen batubara semi-soft coking, sub-bituminus dan berkadar belerang rendah yang ramah lingkungan dengan memadukan operasional pertambangan, pengolahan dan logistik secara terintegrasi melalui anak-anak perusahaan yang bergerak di berbagai bidang usaha, mulai dari pertambangan, pengelolaan jasa pelabuhan, pemuatan batubara, pengangkutan dengan tongkang, kontraktor dan jasa sewa alatalat berat.

Rasio keuangan ada banyak jumlahnya dan setiap rasio itu mempunyai kegunaan masing-masing. Bagi investor, sebelum melakukan investasi tentunya mereka dapat dari investasinya. Jika rasio tersebut tidak mempresentasikan tujuan dari analisis yang akan dia lakukan maka rasio tersebut tidak dipergunakan. Rasiorasio yang di pergunakan dalam penelitian ini adalah : (1) Rasio profitabilitas adalah rasio untuk mengukur prestasi perusahaan dalam hal mendapatkan keuntungan atau rentabilitas usaha atas modal yang kita gunakan. Rasio ini merupakan alat pengukur prestasi dari manajemen perusahaan atau pengelola perusahaan maupun wirausaha sendiri. (2) Rasio solvabilitas adalah rasio yang menunjukan besarnya aktiva sebuah perusahaan yang di danai dengan uang. Artinya, seberapa besar beban utang yang ditanggung dengan aktivanya. (3) Rasio likuiditas, yaitu rasio yang mengukur kemampuan perusahaan dalam memenuhi kewajiban hutang jangka pendeknya secara tapat waktu. (4) Rasio aktivitas yaitu rasio yang menggambarkan sejauh mana perusahaan mempergunakan sumber daya yang dimilikinya guna menunjang aktivitas perusahaan untuk memperoleh hasil yang maksimal. Adapun tujuan dari penelitian ini adalah untuk mengetahui kinerja keuangan dengan menganalisa rasio terkait selama rentang waktu tahun 2015 samapai 2017.

\section{TINJAUAN PUSTAKA}

Manajemen Keuangan

Manajemen keuangan memegang peranan yang sangat penting. Seiring dengan 
perkembangannya, tugas manajer keuangan tidak hanya mencatat, membuat laporan, mengendalikan posisi kas, membayar tagihan-tagihan dan mencari dana. Akan tetapi, manajer keuangan juga harus mampu menginvestasikan dana, mengatur kombinasi sumber dana yang optimal, serta pendistribusian keuntungan (pembagian dividen) dalam rangka meningkatkan nilai perusahaan maupun likuiditasnya. Pengaturan kombinasi sumber dana (hutang dan modal sendiri) berikut kebijakan-kebijakan dividen merupakan penentu besar kecilnya beban finansial dan rasio finansial. Semua variabel tersebut akan mempengaruhi penilaian perusahaan secara keseluruhan untuk dapat menjalankan usaha setiap perusahaan membutuhkan dana. Menurut Harjito dan Martono (2012:4) mengemukakan bahwa manajemen keuangan ialah : Manajemen keuangan (financial management), atau dalam literature lain disebut pembelanjaan, adalah segala aktivitas perusahaan yang berhubungan dengan bagaimana secara menyeluruh. Dengan kata lain manajemen keuangan merupakan manajemen (pengelolaan) mengenai bagaimana memperoleh aset, mendanai aset dan mengelola aset untuk mencapai tujuan perusahaan.

\section{Fungsi Manajemen}

Prinsip manajemen perusahaan menuntut agar baik dalam memperoleh maupun menggunakan dana harus didasarkan pada pertimbangan efisiensi dan efektivitas. Pengertian manajemen mengandung fungsi-fungsi perencanaan, pengarahan dan pengendalian. Berhubung dengan itu maka perlu ada perencanaan pengendalian yang baik dalam menggunakan maupun dalam pemenuhan kebutuhan dana. Menurut Sutrisno (2009:5) fungsi manajemen keuangan yaitu:

1. Keputusan investasi adalah masalah bagaimana manajer keuangan harus mengalokasikan dana ke dalam bentuk-bentuk investasi yang dapat mendapatkan keuntungan dimasa yang akan datang. Bentuk, macam dan komposisi dari investasi tersebut akan mempengaruhi dan menunjanng tingkat keuntungan di masa depan. Oleh karena itu investasi akan mengandung risiko atau ketidakpastian. Risiko dan hasil yang diharapkan dari investasi itu akan sangat mempengaruhi 
pencapaian tujuan, kebijakan maupun nilai perusahaan.

2. Keputusan pendanaan ini sering disebut sebagai kebijakan struktur modal. Pada keputusan ini manajer keuangan dituntut untuk mempertimbangkan dan meganalisis kombinasi dari sumbersumber dana yang ekonomis bagi perusahaan guna membelanjai kebutuhan-kebutuhan investasi serta kegiatan usahanya.

\section{Pengertian Kinerja Keuangan}

Kinerja keuangan dapat dikatakan sebagai usaha formal yang dilaksanakan perusahaan untuk mengevaluasi efisien dan efektivitas dari aktivitas perusahaan yang telah dilaksanakan pada periode waktu tertentu. Kinerja keuangan dengan kata lain adalah penentuan ukuran-ukuran tertentu yang dapat mengukur keberhasilan suatu organisasi atau perusahaan dalam menghasilkan laba. Pengukuran kinerja didefinisikan sebagai "performing measurement", yaitu kualifikasi dan efisiensi serta efektifitas perusahaan dalam pengoperasian bisnis selama periode akuntansi.

Kinerja keuangan adalah suatu analisis yang dilakukan untuk melihat sejauh mana suatu perusahaan telah melaksanakan dengan menggunakan aturan-aturan pelaksanaan keuangan secara baik dan benar. Kinerja keuangan juga dapat disebut suatu gambaran tentang kondisi keuangan suatu perusahaan yang dianalisis dengan alatalat analisis keuangan, sehingga dapat diketahui mengenai baik ataupun buruk keadaan keuangan suatu perusahaan yang mencerminkan prestasi kerja dalam peiode tertentu.Hal ini sangat penting agar sumber daya digunakan secara optimal dalam menghadapi perubahan lingkungan.

Menurut Fahmi (2014:2) kinerja keuangan adalah: Kinerja keuangan adalah suatu analisis yang dilakukan untuk melihat sejauh mana suatu perusahaan telah melaksanakan dengan menggunakan aturan-aturan pelaksana keuangan secara baik dan benar.

\section{Laporan Keuangan}

Suatu laporan keuangan (financial statement) akan menjadi lebih bermanfaat untuk pengambilan keputusan, apabila dengan informasi laporan keuangan tersebut dapat diprediksi apa yang akan terjadi di masa yang akan datang. Mengolah lebih lanjut laporan keuangan melalui proses perbandingan, evaluasi dan analisis tren, 
akan diperoleh prediksi tentang apa yang mungkin akan terjadi di masa mendatang, sehingga disinilah laporan keuangan tersebut begitu diperlukan. Yang nanti hasilnya akan mampu membantu dalam memberikan pertimbangan mengenai kondisi perusahaan/badan usaha di masa mendatang.Menurut Harjito dan Martono (2013:51) : laporan keuangan ialah merupakan ikhtisar mengenai keadaan keuangan pada suatu saat tertentu. Laporan keuangan secara garis besar dibedakan menjadi 4 macam, yaitu laporan neraca, laporan laba rugi, laporan perubahan modal dan aliran kas.

\section{Jenis-Jenis Laporan Keuangan}

Menurut Kasmir (2008:6) Laporan keuangan adalah laporan yang menunjukkan kondisi keuangan perusahaan pada saat ini atau dalam suatu periode tertentu. Berikut adalah beberapa jenis laporan keuangan yaitu :

1. Neraca, neraca berisi gambaran posisi keuangan, yang menunjukkan aktiva, kewajiban dan ekuitas dari suatu perusahaan pada tanggal tertentu. Begitu juga kewajiban jangka pendek tentu akan dipisahkan dengan kewajiban jangka panjang.
2. Laporan laba rugi, laporan laba rugi adalah ringkasan aktivitas transaksi pada perusahaan yang akan berpengaruh pada stabilitas, resiko dan prediksi pada suatu periode yang menghasilkan hasil usaha bersih atau kerugian yang timbul dari kegiatan usaha dan aktivitas lainnya. Laporan laba rugi perusahaan menampilkan berbagai unsur kinerja keuangan yang diperlukan bagi penyajian secara wajar.

3. Laporan perubahan ekuitas, laporan perubahan ekuitas adalah laporan yang menyajikan peningkatan maupun penurunan aktiva-aktiva bersih atau kekayaan perusahaan selama periode tertentu yang didasarkan prinsip-prinsip pengukuran tertentu yang dianut yang harus diungkapkan dalam laporan keuangan.

4. Laporan arus kas informasi, laporan arus kas informasi pada umumnya laporan arus kasbanyak digunakan sebagai indikator dari jumlah, waktu dan kepastian arus kas masa depan. Selain itu, arus kas berfungsi meneliti kecermatan dan ketepatan/perkiraan arus kas masa depan yang telah dibuat 
sebelumnya dan dalam menentukan hubungan antara profitabilitas dan arus kas bersih serta dampak perubahan harga yang diklasifikasikan menurut aktiva operasi investasi dan pendanaan.

5. Catatan atas laporan keuangan, catatan atas laporan keuangan meliputi penjelasan naratif atau rincian jumlah yang tertera dalam neraca, laporan laba rugi, laporan arus kas dan laporan perubahan ekuitas serta informasi tambahan seperti kewajiban kontijensi dan komitmen. Catatan atas laporan keuangan juga mencakup informasi yang diharuskan dan dianjurkan untuk diungkapkan dalam PSAK serta pengungkapan-pengungkapan lain yang diperlukan untuk menghasilkan penyajian laporan keuangan secara wajar.

Menurut Sutrisno

laporan keuangan merupakan hasil akhir akhir dari proses akuntansi yang meliputi dua laporan utama yakni neraca dan laporan laba rugi.

1. Neraca adalah laporan yang menunjukkan posisi keuangan suatu perusahaan pada saat tertentu.
2. Aktiva lancar adalah aktiva yang masa perputarannya kurang atau maksimal dalam satu tahun.

3. Aktiva tetap adalah aktiva yang masa manfaatnya lebih dari satu tahun atau berjangka panjang.

4. Hutang jangka pendek (hutang lancar) adalah hutang yang masa jatuh temponya kurang dari satu tahun seperti hutang dagang, hutang gaji, hutang pajak,dan hutang bank jangka pendek.

5. Hutang jangka panjang adalah hutang yang berjangka lebih satu tahun, seperti hutang bank jangka panjang, hutang obligasi, maupun hutang hipotik.

6. Laporan laba rugi adalah laporan yang menunjukkan hasil kegiatan perusahaan dalam jangka waktu tertentu.

\section{Analisis Rasio Keuangan}

Rasio keuangan atau financial ratio ini sangat penting gunanya untuk melakukan analisa terhadap kondisi keuangan perusahaan. Bagi investor jangka pendek dan menengah pada umumnya lebih banyak tertarik kepada kondisikeuangan jangka pendek dan kemampuan perusahaan untuk membayar dividen yang memadai. 
Salah satu metode yang dapat dilakukan untuk menganalisa laporan keuangan adalah analisis rasio. Analisis rasio adalah cara analisa dengan menggunakan perhitungan-perhitungan perbandingan atas data kuantitatif yang ditunjukkan dalam neraca maupun laba rugi. Pada dasarnya perhitungan rasiorasio keuangan adalah untuk menilai kinerja keuangan perusahaan di masa lalu, saat ini, dan kemungkinannya di masa depan.

Pada umumnya, rasio keuangan bermacam-macam tergantung kepada kepentingan dan kegunaannya, begitu pula perbedaan jenis perusahaan juga dapat menimbulkan perbedaan rasiorasionya. Analisis rasio keuangan juga bisa digunakan untuk menilai kinerja keuangan perusahaan di masa lalu. saat ini dan berbagai kemungkinannya di masa depan.

Analisis rasio keuangan sendiri dimulai dengan laporan keuangan dasar yaitu dari neraca (balance sheet), perhitungan rugi laba (income statement) dan laporan arus kas (cash flow statement). Perhitungan rasio keuangan akan menjadi lebih jelas jika dihubungkan antara lain dengan menggunakan pola historis perusahaan tersebut, yang dilihat perhitungan pada sejumlah tahun guna menentukan apakah perusahaan membaik atau memburuk, atau melakukan perbandingan dengan perusahaan lain dalam industri yang sama. Menurut Sirait (2017:37) secara umum analisis rasio keuangan terhadap 3 hal, yaitu:

1. Rasio cakupan (a coverage ratio), yaitu pengukuran kemampuan perusahaan untuk menyelesaikan utang jangka pendek (liquidity) dan keamanan terhadap utang jangka panjang (safety/solvability).

2. Rasio hasil (a return ratio), yaitu pengukuran kemampuan perusahaan menggunakan sumber daya yang ada efektif, sehingga sesuai dengan sasaran atau tujuan perusahaan.

3. Rasio penggantian (a turnover ratio), yaitu pengukuran kemampuan perusahaan untuk mendapatkan laba atau pengganti seluruh yang telah dikorbankan termasuk harapan.

Menurut Hery (2015:138) Rasio keuangan merupakan suatu perhitungan rasio dengan menggunakan laporan keuangan yang berfungsi sebagai alat ukur dalam menilai kondisi keuangan dan kinerja perusahaan. Rasio keuangan adalah angka yang diperoleh dari hasil 
perbandingan antara satu pos laporan keuangan dengan pos lainnya yang mempunyai hubungan yang relevan dan signifikan. Perbandingan dapat dilakukan antara satu pos dengan pos lainnya dalam satu laporan keuangan atau antarpos yang ada di antara laporan keuangan.

\section{Rasio Profitabilitas}

Profitabilitas adalah hasil bersih dari serangkaian kebijakan dan keputusan.Rasio profitabilitas (profitability ratio) menunjukkan pengaruh gabungan dari likuiditas, manajemen aktiva dan utang terhadap hasil operasi.

\section{Rasio Solvabilitas}

Menurut Hery (2015: 163) rasio solvabilitas yaitu dalam menjalankan kegiatannyatentu saja setiap perusahaan membutuhkan ketersediaan dana dalam jumlah yang memadai. Dana ini tidak hanya dibutuhkan untuk membiayai jalannya kegiatan operasional perusahaan saja, melainkan juga untuk membiayai aktivitas investasi perusahaan seperti biaya untuk mengganti atau membeli tambahan peralatan dan mesin produksi yang baru, membuka kantor cabang baru, melakukan ekspansi bisnis dan sebagainya.

\section{Rasio Likuiditas}

Rasio likuiditas adalah suatu indikator mengenai kemampuan perusahaan yang membayar segala kewajiban financial jangka pendek pada saat jatuh tempo dengan menggunakan aktiva lancar yang masih tersedia atau kata lainnya dapat menggambarkan kemampuan perusahaan dalam memenuhi utang (kewajiban) jangka pendek.

\section{Rasio Aktivitas}

Menurut Fahmi (2015:77) Rasio aktivitas adalah rasio yang menggambarkan sejauh mana suatu perusahaan mempergunakan sumber daya yang dimilikinya guna menunjang aktivitas perusahaan, dimana penggunaan aktivitas ini dilakukan secara singkat maksimal dengan maksud memperoleh hasil yang maksimal. Rasio ini bagi banyak praktisi dan analisis bisnis menyebutnya juga sebagai rasio pengelolaan aset (asset management ratio).

\section{METODE PENELITIAN}

\section{Jenis Penelitian}

Penelitian ini data yang digunakan adalah data sekunder, yaitu data yang dipublikasikan oleh lembaga yang bergerak dalam bidang pasar 
modal, data yang diperoleh dari sumber informasi Bursa Efek Indonesia. Guna melengkapi kajian pustaka yang relevan dengan bahasan ini, maka dalam penelitian ini juga dikumpulkan data dari berbagai sumber bacaan seperti buku-buku, laporan keuangan, dan sebagainya.

Jenis data dalam penelitian ini adalah data sekunder berupa data laporan Posisi keuangan PT. Bayan Resources pada tahun 2015-2017. Data-data ini dihimpun dengan melakukan penelitian kepustakaan /Library Research yaitu data penelitian ini diambil dari IDX tahun $2015-2017$

\section{Alat Analisis}

Alat analisis yang digunakan yaitu rasio keuangan yang meliputi : rasio profitabilitas, rasio solvabilitas, rasio likuiditas dan rasio aktivitas.

1. Rasio Profitabilitas:

$$
R O A=\frac{\text { Laba Bersih }}{\text { total aset }} \times 100 \%
$$

2. Rasio Solvabilitas :
Debt To Equity Ratio= $\frac{\text { total hutang }}{\text { total modal }} \times 100 \%$

3. Rasio Likuiditas :

Current Ratio $=\frac{\text { aset lancar }}{\text { hutang lancar }} \times 100 \%$

4. Rasio Aktivitas

Total Asset Turnover $=\frac{\text { penjualan }}{\text { total aset }} \times 1$

\section{ANALISIS DAN PEMBAHASAN}

\section{Analisis}

Analisis laporan keuangan bertujuan untuk mengetahui besarnya perubahan kinerja keuangan PT. Bayan Resources, Tbk selama tahun 2015 sampai dengan tahun 2017 maka dilakukan penelitian, perusahaan bisa melihat perubahan yang terjadi di laporan keuangan perusahaan PT. Bayan resources, Tbk.

\section{Analisis Rasio Profitabilitas}

Perhitungan rasio profitabilitas menggunakan Return On Assets dengan persentase laba bersih dibandingkan dengan total aset, maka digunakan rumus:

$\mathrm{ROA}=\frac{\text { laba bersih }}{\text { total aset }} \times 100 \%$

Tabel 2.1 Return On Assets

\begin{tabular}{ccc}
\hline Tahun & Return On Assets & Keterangan \\
\hline 2015 & $-0,0727$. & Menurun \\
\hline 2016 & 0,0357 & Meningkat \\
\hline 2017 & 0,472 & Meningkat
\end{tabular}

Sumber: data diolah 


\section{Analisis Rasio Solvabilitas}

Perhitungan rasio solvabilitas total utang dengan total aset, maka menggunakan Debt Equity Ratio (DER) digunakan rumus:

dengan mengukur perbandingan antara

$$
\mathrm{DER}=\frac{\text { total hutang }}{\text { ekuitas }} \times 100 \%
$$

Tabel 2.2. Debt Equity Ratio

\begin{tabular}{ccc}
\hline Tahun & Debt Equity Ratio & Keterangan \\
\hline 2015 & 4,447558354 & Meningkat \\
\hline 2016 & 3,383111304 & Menurun \\
\hline 2017 & 0,723829629 & Menurun
\end{tabular}

Sumber: data diolah

\section{Analisis Rasio Likuiditas}

Perhitungan rasio likuiditas maka digunakan rumus:

menggunakan Current Ratio dengan Tahun 2015

mengukur perbandingan antara total Current Ratio $=\frac{\text { aktiva lancar }}{\text { hutang lancar }} \times 100 \%$

aktiva lancar dengan total hutang lancar,

Tabel 2.3. Current Ratio

\begin{tabular}{ccc}
\hline Tahun & Current Ratio & Keterangan \\
\hline 2015 & 1,885391749 & Meningkat \\
\hline 2016 & 2,546098197 & Meningkat \\
\hline 2017 & 1,024147115 & Menurun
\end{tabular}

Sumber: data diolah

\section{Analisis Rasio Aktivitas}

Rasio Aktivitas diukur dari Total

Assets Turnover (TATO), rasio ini digunakan untuk mengukur keefektifan total aset yang dimiliki perusahaan

Tabel 2.4. TATO dalam menghasilkan penjualan, maka digunakan rumus:

Total Assets Turnover $=\frac{\text { penjualan }}{\text { total } \text { aset }} \times 1$

\begin{tabular}{ccc}
\hline Tahun & TATO & Keterangan \\
\hline 2015 & 0,49 & Menurun \\
\hline 2016 & 0,67 & Meningkat \\
\hline 2017 & 1,20 & Meningkat
\end{tabular}

Sumber: data diolah 


\section{PEMBAHASAN}

\section{Rasio Profitabilitas diukur dari (Return on Assets)}

Return on Assets (ROA) pada tahun 2015 sebesar - 0,727\% hal ini menunjukkan bahwa setiap Rp. 1,- total aset yang digunakan perusahaan memperoleh pengembalian sebesar Rp.0,727 Menurut sumber annual report tahun 2015 PT Resource Alam Indonesia Tbk berhasil meningkatkan kinerja keuangan tetapi penjualan batubara pada tahun ini masih tidak stabil sehingga PT Bayan Resource Tbk perlu menganalisis lagi penjualan batubara ke setiap negara.

Return on Assets (ROA) pada tahun 2016 sebesar $0,357 \%$ hal ini menunjukkan bahwa setiap Rp 1,- total aset yang digunakan perusahaan memperoleh pengembalian sebesar Rp. 0,357. Menurut sumber annual report volume penjualan batubara secara keseluruhan mengalami kenaikan sebesar 8,0\% dari 3.455.234 MT menjadi 3.178.345 MT yang disebabkan oleh meningkatnya harga batubara newcastle.

Return on Assets (ROA) pada tahun 2017 sebesar Rp. 4,72\% hal ini menunjukkan bahwa setiap Rp. 1,- total aset yang digunakan perusahaan memperoleh pengembalian sebesar $\mathrm{Rp}$. 4,72 yang terjadi pada tahun ini. Menurut sumber annual report PT. Bayan Resource Tbk berhasil meraih laba yang seimbang pada tahun ini terlihat dari laba perusahaan yang meningkat, pertumbuhan pendapatan komprehensif yang signifikan dan kinerja keuangan perusahaan yang baik. Rasio Solvabilitas di ukur dari (Debt to Equity Ratio)

Debt to Equity Ratio (DER) pada tahun 2015 sebesar $44,47 \%$ Hal ini menunjukkan bahwa setiap Rp. 1,utang PT Bayan Resource Tbk dijamin oleh Rp.44,47 modal pemilik perusahaan.

\section{Debt to Equity Ratio} (DER) pada tahun 2016 sebesar 33,8\% hal ini menunjukkan bahwa setiap Rp. 1,- utangPT Bayan Resource Tbk dijamin oleh Rp.33,8 modal pemilik perusahaan dan PT Bayan Resource Tbk mengalami penurunan dari tahun 2015 sebesar 5.593.879. Menurut sumber annual report penurunan tersebut terjadi karena kombinasi kenaikan dan penurunan dari utang usaha pihak ketiga, utang lain-lain, utang pajak, beban akrual, utang sewa pembiayaan jangka pendek, uang jaminan jangka pendek, liabilitas 
imbalan kerja jangka pendek, pendapatan diterima dimuka, utang sewa pembiayaan jangka panjang, liabilitas imbalan kerja jangka panjang, uang jaminan jangka panjang, penyisihan reklamasi.

\section{Debt to Equity Ratio (DER)} pada tahun 2017 sebesar 7,23\% hal ini menunjukkan bahwa setiap Rp. 1,utang PT Bayan Resource dijamin oleh Rp. 7,23 modal pemilik perusahaan. Menurut sumber annual report turunnya utang tahun ini sehubungan dengan turunya produksi batubara bulan Desember 2016, sehingga jumlah tagihan atas pekerjaan penambangan batubara lebih sedikit dibandingkan dengan periode yang sama dengan tahun lalu.

Oleh karena itu debt to equity ratio yang mengalami penurunan dari tahun 2015 sampai tahun 2017 menunjukkan hal yang baik, karena jumlah ekuitas perusahaan mengalami kenaikan lebih besar dibandingkan kenaikan total utang yang dimiliki.

Rasio Likuiditas diukur dari (Current Ratio)

Current Ratio pada tahun 2015 sebesar $18,85 \%$ hal ini menunjukkan bahwa atas setiap Rp. 1,- utang lancar perusahaan dijamin oleh Rp. 18,85 aset lancar perusahaan. Menurut sumber annul report turunnya nilai utang disebabkan selain faktor adanya pelunasan juga dipengaruhi oleh penurunan nilai tukar rupiah terhadap dollar Amerika.

Current Ratio pada tahun 2016 sebesar 25,46\% menunjukkan bahwa setiap Rp. 1,- utang lancar perusahaan dijamin oleh Rp. 25,46 aset lancar perusahaan.

Current Ratio pada tahun 2017 sebesar $10,24 \%$ hal ini menunjukkan bahwa setiap Rp. 1,- utang lancar perusahaan dijamin oleh Rp. 10,24 aset lancar perusahaan. Menurut annual report penurunan ini disebabkan karena kombinasi dari penurunan penerimaan atas penjualan batubara terkait turunnya rata-rata harga jual dan di imbangi dengan turunnya pembayaran ke pemasok/pelanggan terkait turunnya biaya tunai perseroan.

Current ratio mengalami penurunan pada tahun 2017 menunjukkan bahwa, kemampuan perusahaan menurun dalam hal memenuhi kewajiban jangka pendeknya.

Rasio Aktivitas diukur dari (Total Assets Turnover 
Total assets turnover tahun 2015 sebesar 0,49 kali yang artinya mengalami penurunan pada tahun ini. Menurut sumber annual report penjualan bersih perseroan untuk periode 12 bulan yang berakhir 31 Desember 2015 mengalami penurunan $30 \%$ menjadi sebesar USD135.766.894 dari sebelumnya USD193.474.442. Penurunan penjualan tersebut disebabkan oleh melemahnya harga jual batubara akibat kelebihan persediaan batubara di pasar internasional sehingga permintaan batubara menurun.

Total assets turnover tahun 2016 sebesar 0,67 kali yang artinya mengalami kenaikan pada tahun ini. Menurut sumber annual report beban pokok perseroan terhadap penjualan bersih mengalami penurunan $25,50 \%$ menjadi sebesar USD84.539.244 dibandingkan tahun sebelumnya sebesar USD113.470.275. Penurunan beban pokok disebabkan turunnya tarif penambangan serta turunnya volume produksi batubara dibandingkan tahun sebelumnya.

Total assets turnover tahun 2017 sebesar 1,20 kali yang artinya mengalami penurunan pada tahun ini. Menurut annual report beban penjualan perseroan selama periode 12 bulan yang berakhir tahun 2016 turun menjadi USD2.675.681 dari tahun lalu sebesar USD10.866.302 atau turun sebesar $75,38 \%$. Penurunan biaya penjualan terutama disebabkan karena sebagian besar penjualan batubara perseroan pada tahun 2016 dilakukan dengan memakai harga jual FOB tongkang (Barge) sedangkan pada tahun 2015 penjualan memakai harga jual di atas kapal (Vessell). Perubahan syarat dan kondisi syarat penjualan dari FOB Vessell (kapal) ke FOB Barge (tongkang) merupakan faktor utama turunnya biaya transshipment pada periode tahun 2017.

\section{KESIMPULAN}

1. Rasio profitabilitas pada PT. Bayan Resource Tbk ditinjau dari ROA (Return On Asset)pada periode 2015-2017 mengalami kenaikan.

2. Rasio solvabilitas pada PT. Bayan Resource Tbk ditinjau dari DER (Debt Equity Ratio) pada periode 2015-2016 mengalami penurunan.

3. Rasio solvabilitas pada PT. Bayan Resource Tbk ditinjau dari DER (Debt Equity Ratio)pada periode 2016-2017 mengalami penurunan.

4. Rasio likuiditas pada PT. Bayan Resource Tbk ditinjau dari Rasio Lancar (Current Ratio)pada periode 2015-2016 mengalami penurunan. 
5. Rasio likuiditas pada PT. Bayan Resource Tbk ditinjau dari Rasio Lancar (Current Ratio) pada periode 2016-2017 mengalami penurunan.

6. Rasio aktivitas pada PT. Bayan Resource Tbk ditinjau dari Perputaran Total Aktiva (Total Asset Turnover) pada periode 20152017 mengalami penurunan.

7. Rasio aktivitas pada PT. Bayan Resource Tbk ditinjau dari Perputaran Total Aktiva (Total Asset Turnover) pada periode20162017 mengalami kenaikan.

\section{SARAN}

Beberapa saran yang dapat peneliti sampaikan berdasarkan penelitian yang telah dilakukan adalah:

Perusahaan harus lebih meningkatkan efektivitas dan efisiensi pada perusahaan, jika kinerja keuangan di dalam perusahaan baik maka akan memberikan kontribus yang baik juga, sebaliknya jika kinerja keuangan di dalam perusahaan buruk maka akan sangat beresiko bagi perusahaan.

Investor perlu melakukan pertimbangan dan harus menyikapi segala hal yang berkaitan dengan kinerja keuangan di dalam perusahaan ini, karena kinerja keuangan di dalam suatu perusahaan sangat berperan penting dalam kelangsungan hidup suatu perusahaan.

Peneliti selanjutnya yang menggunakan penelitian yang sama disarankan untuk menambah variabelvariabel lainnya juga dan memperpanjang tahun periode yang pengamatan penelitian, sehingga data yang diolah lebih mewakilkan hasil dari kinerja keuangan suatu perusahaan.

\section{DAFTAR PUSTAKA}

Agus Harjito dan Martono. 2012. Manajemen Keuangan. Edisi ke-2. Yogyakarta: Ekonisia.

Agus D., Harjito dan Martono. 2013. Manajemen Keuangan, Edisi kedua. Yogyakarta: Ekonisia.

Fahmi, Irham. 2014. Analisis laporan Keuangan. Bandung: Alfabeta

Hery. 2015. Analisis Laporan Keuangan. Edisi 1. Yogyakarta: Center For Academic Publishing Services.

Helfert, Erich A .1996. Teknik Analisis Keuangan. Erlangga: Jakarta.

Husnan, Suad dan Enny Pudjiastuti. 2015. Dasar-Dasar Manajemen Keuangan, Edisi Ketujuh. UPP STIM YKPN: Yogyakarta.

Kasmir. 2001. Bank dan Lembaga Keuangan Lainnya. Rajawali Press: Jakarta.

Kasmir. 2008. Analisis Laporan Keuangan. Rajawali Pers: Jakarta. 
Sirait, Pirmatua. 2017. Analisa Laporan Keuangan. Graha Ilmu: Jakarta.

Sudaryono. 2017. Pengantar Manajemen Teori dan Kasus. : Cap Publishing: Jakarta

Sutrisno. 2009. Manajemen Keuangan
Teori, Konsep dan Aplikasi, Edisi Pertama, Cetakan Ketujuh. Penerbit Ekonisia: Yogyakarta.

Wiyono, Gendro dan Kusuma, Hadri. 2017. Manajemen Keuangan Lanjutan Berbasis Corporate Value Creation Edisi kesatu. UPP STIM YKPN: Yogyakarta. 